\title{
Dielectric properties of Bi-substituted LDHs synthesized by co-precipitation and sol-gel methods
}

\author{
DENIS SOKOL ${ }^{1}$, MAKSIM IVANOV $^{2}$, ANDREI N. SALAK ${ }^{3}$, ROBERTAS GRIGALAITIS ${ }^{2}$, JURAS \\ BANYS $^{2}$, AIVARAS KAREIVA ${ }^{1, *}$ \\ ${ }^{1}$ Institute of Chemistry, Vilnius University, Naugarduko 24, LT-03225 Vilnius, Lithuania \\ 2 aculty of Physics, Vilnius University, LT-10222 Vilnius, Lithuania \\ ${ }^{3}$ Department of Materials and Ceramic Engineering/CICECO, University of Aveiro, 3810-193 Aveiro, Portugal
}

\begin{abstract}
Magnesium-aluminum-bismuth layered double hydroxides $\left(\mathrm{Mg}_{3} \mathrm{Al}_{1-\mathrm{x}} \mathrm{Bi}_{\mathrm{x}}\right.$; LDHs) were prepared using both coprecipitation and sol-gel methods. For the preparation of $\mathrm{Mg} / \mathrm{Al} / \mathrm{Bi} \mathrm{LDH}$ by the co-precipitation method, the appropriate amounts of dissolved starting materials $\left(\mathrm{Al}\left(\mathrm{NO}_{3}\right)_{3} \cdot 9 \mathrm{H}_{2} \mathrm{O}, \mathrm{Mg}\left(\mathrm{NO}_{3}\right)_{2} \cdot 6 \mathrm{H}_{2} \mathrm{O}\right.$ and $\left.\mathrm{Bi}\left(\mathrm{NO}_{3}\right)_{3} \cdot 5 \mathrm{H}_{2} \mathrm{O}\right)$ were mixed with a solution of $\mathrm{NaHCO}_{3}: \mathrm{NaOH}$. In the sol-gel processing, the precursor $\mathrm{Mg}-\mathrm{Al}-\mathrm{Bi}-\mathrm{O}$ gels were synthesized using the same starting materials and ethylene glycol as complexing agent. The mixed-metal oxides obtained by subsequent heating of $\mathrm{Mg}-\mathrm{Al}-\mathrm{Bi}-\mathrm{O}$ gels at $650{ }^{\circ} \mathrm{C}$ were reconstructed to $\mathrm{Mg}_{3} \mathrm{Al}_{1-\mathrm{x}} \mathrm{Bi}_{\mathrm{x}} \mathrm{LDHs}$ in water at $80{ }^{\circ} \mathrm{C}$. All the synthesized products were characterized by X-ray diffraction (XRD) analysis, scanning electron microscopy (SEM) and dielectric measurements.
\end{abstract}

Keywords: layered double hydroxide; bismuth substitution; co-precipitation; sol-gel; dielectric properties

\section{Introduction}

In the known $\mathrm{M}^{\mathrm{II}}-\mathrm{M}^{\mathrm{III}} \mathrm{LDHs}, \mathrm{M}^{\mathrm{II}}$ is a cation of magnesium or a $4^{\text {th }}$-period transition metal from iron to zinc, and $\mathrm{M}^{\mathrm{III}}$ is, as a rule, $\mathrm{Al}, \mathrm{Ga}, \mathrm{Fe}$, or $\mathrm{Cr}$ [1]. Some authors declared preparation of $\mathrm{M}^{\mathrm{II}}$ $\mathrm{M}^{\mathrm{III}} \mathrm{LDH}$, where $\mathrm{M}^{\mathrm{III}}$ is $\mathrm{Bi}[2,3]$ but the respective XRD patterns were either not presented or very doubtful. Recently, the preparation of LDH compounds with $\mathrm{M}^{\mathrm{III}}=\mathrm{Bi}$ using a novel alkoxide-free sol-gel method has been reported [4].

The Bi-containing LDH could be of a great interest, since $\mathrm{Bi}^{\mathrm{III}}$ has a stereochemically active lone pair of electrons. This feature of bismuth is associated with the onset of unusual dielectric relaxation in oxygen octahedral phases that contain $\mathrm{Bi}^{\mathrm{III}} \mathrm{co}-$ ordinated by twelve $(8+4)$ oxygens $[5,6]$. Besides, polar (antipolar) orderings in oxygen octahedral multiferroics typically result from parallel (antiparallel) displacements of $\mathrm{Bi}^{\mathrm{III}}[7,8]$.

In $\mathrm{LDH}$ structure, the octahedra $\mathrm{M}^{\mathrm{II}} \mathrm{O}_{6}$ and $\mathrm{M}^{\mathrm{III}} \mathrm{O}_{6}$ in hydroxide layer are face-linked [4].

*E-mail: aivaras.kareiva@chgf.vu.lt
Therefore, the LDH containing relatively small divalent cations and relatively large trivalent cations are stable at the cation ratio of $\mathrm{M}^{\mathrm{II}} / \mathrm{M}^{\mathrm{III}}=3: 1$ with the ordered arrangement, when every $\mathrm{M}^{\mathrm{III}} \mathrm{O}_{6}$ octahedron is coordinated by the $\mathrm{M}^{\mathrm{II}} \mathrm{O}_{6}$ octahedra only (Fig. 1) [4].

It is well known that structural features of such type of compounds are very dependent on the used fabrication method $[9,10]$. The main aim of this study was to compare dielectric properties of $\mathrm{Mg}_{3} \mathrm{Al}_{1-\mathrm{x}} \mathrm{Bi}_{\mathrm{x}} \mathrm{LDHs}$ prepared by co-precipitation and sol-gel methods.

\section{Experimental}

For the synthesis of LDHs the following materials have been used: $\mathrm{Al}\left(\mathrm{NO}_{3}\right)_{3} \cdot 9 \mathrm{H}_{2} \mathrm{O}(98 \%$, POCH S.A.), $\mathrm{Mg}\left(\mathrm{NO}_{3}\right)_{2} \cdot 6 \mathrm{H}_{2} \mathrm{O}$ (99\%, Fluka); $\mathrm{Bi}\left(\mathrm{NO}_{3}\right)_{3} \cdot 5 \mathrm{H}_{2} \mathrm{O}\left(98 \%\right.$, Fluka), $\mathrm{HNO}_{3}(66 \%$, REACHEM s.r.o.), ethylene glycol $\mathrm{C}_{2} \mathrm{H}_{6} \mathrm{O}_{2}(99 \%$, Sigma-Aldrich), $\mathrm{CH}_{3} \mathrm{COOH}$ (99\%, REACHEM s.r.o.), $\mathrm{NaHCO}_{3}$ (99\%, REACHEM s.r.o.) and $\mathrm{NaOH}$ (66 \%, REACHEM s.r.o.). Deionized water was used in all syntheses, preparation of solutions 


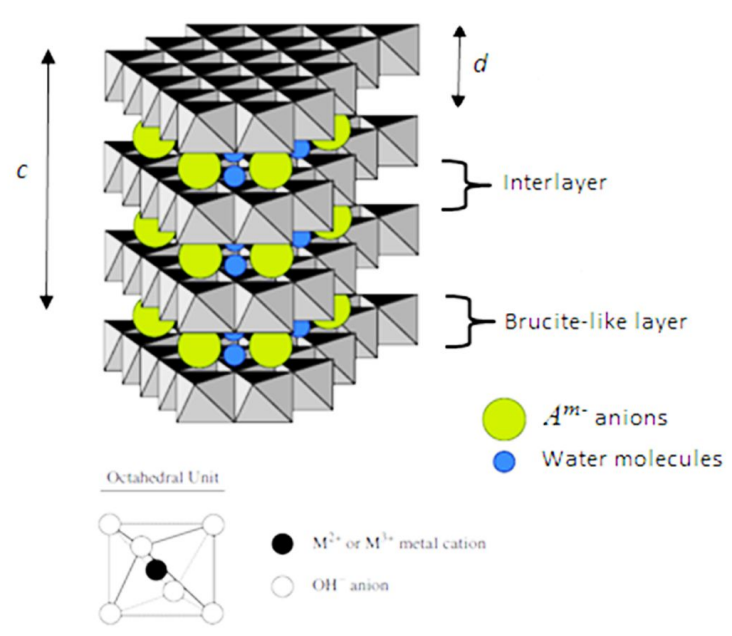

Fig. 1. A schematic representation of LDH structure of a 3R polytype [4], where the lattice parameter $\mathrm{c}$ and the basal spacing $\mathrm{d}$ are related to each other as $\mathrm{c}=3 \mathrm{~d}$.

and washing of final compounds. $\mathrm{Mg}_{3} \mathrm{Al}_{1-\mathrm{x}} \mathrm{Bi}_{\mathrm{x}}$ LDHs ( $\mathrm{x}=0,0.1$ and 0.2 ) were synthesized by co-precipitation method by mixing aqueous solutions of $\mathrm{Al}\left(\mathrm{NO}_{3}\right)_{3} \cdot 9 \mathrm{H}_{2} \mathrm{O}$ and $\mathrm{Mg}\left(\mathrm{NO}_{3}\right)_{2} \cdot 6 \mathrm{H}_{2} \mathrm{O}$ in a molar ratio of $\mathrm{Mg}: \mathrm{Al}=3: 1$, appropriate amount of $\mathrm{Bi}\left(\mathrm{NO}_{3}\right)_{3} \cdot 5 \mathrm{H}_{2} \mathrm{O}$ dissolved in $1 \mathrm{M} \mathrm{HNO}_{3}$ and a solution of $\mathrm{NaHCO}_{3}: \mathrm{NaOH}$ in a molar ratio of 1:2 [4]. The solution of metal nitrates was slowly poured into the solution of $\mathrm{NaHCO}_{3}+\mathrm{NaOH}$ $(\mathrm{pH} \approx 12)$ under vigorous stirring. After mixing, the obtained slurry was aged at $80{ }^{\circ} \mathrm{C}$ for $6 \mathrm{~h}$, filtered, washed with distilled water and dried in an oven at $60{ }^{\circ} \mathrm{C} . \mathrm{Mg}_{3} \mathrm{Al}_{1-\mathrm{x}} \mathrm{Bi}_{\mathrm{x}} \mathrm{LDHs}(\mathrm{x}=0,0.1$ and 0.2 ) were also obtained by sol-gel processing. The magnesium and aluminum nitrates were dissolved in $50 \mathrm{~mL}$ of distilled water with addition of $50 \mathrm{~mL}$ of $0.2 \mathrm{M}$ acetic acid and mixed in a molar ratio of $\mathrm{Mg}: \mathrm{Al}=3: 1$. Next, appropriate amount of $\mathrm{Bi}\left(\mathrm{NO}_{3}\right)_{3} \cdot 5 \mathrm{H}_{2} \mathrm{O}$ dissolved in $1 \mathrm{M} \mathrm{HNO}_{3}$ and $2 \mathrm{~mL}$ of ethylene glycol as complexing agent were added under continuous stirring for $4 \mathrm{~h}$ at $80{ }^{\circ} \mathrm{C}$. After slow evaporation of the solvent, the obtained $\mathrm{Mg}-\mathrm{Al}-\mathrm{Bi}-\mathrm{O}$ glycolate precursor gel was dried at $120{ }^{\circ} \mathrm{C}$ for $10 \mathrm{~h}$. The mixed-metal oxides (MMO) were obtained by subsequent heating of the precursor gels at $650{ }^{\circ} \mathrm{C}$ for $3 \mathrm{~h}$. These MMO were used for the successive reconstruction of $\mathrm{Mg}_{3} \mathrm{Al}_{1-\mathrm{x}} \mathrm{Bi}_{\mathrm{X}}$
LDHs in water at $80{ }^{\circ} \mathrm{C}$ for $6 \mathrm{~h}$, at $\mathrm{pH} \approx 8.5$. After the restoration processes, the samples were washed with water and dried in air.

The X-ray powder diffraction (XRD) patterns of the samples were recorded with a conventional Bragg-Brentano geometry ( $\theta$ to $2 \theta$ scans) on Rigaku MiniFlexII diffractometer using $\mathrm{CuK} \alpha$ radiation $(\lambda=1.541838 \AA)$. The patterns were recorded from $8^{\circ}$ to $80^{\circ} 2 \theta$ angle at a step size of $0.02^{\circ}$ and at a speed $5 \% \mathrm{~min}$. Morphology of synthesized compounds was investigated by scanning electron microscopy (SEM) using scanning electron microscope Hitachi SU-70. Dielectric measurements were performed using HP4284A precision LCR meter in $1.2 \mathrm{kHz}$ to $1 \mathrm{MHz}$ frequency range during cooling at a rate of $1.5 \mathrm{~K} / \mathrm{min}$ to $2 \mathrm{~K} / \mathrm{min}$. The samples were in a form of $1.6 \mathrm{~mm}$ thick tablets, with silver paste used to produce contact areas of $49.3 \mathrm{~mm}^{2}$. Temperature ranges were $30 \mathrm{~K}$ to $290 \mathrm{~K}$ for vacuumed samples and $70 \mathrm{~K}$ to $390 \mathrm{~K}$ for non-vacuumed samples.

\section{Results and discussion}

It is known, that formation of layered structure becomes problematic when the amount of bismuth exceeds $20 \%$ in $\mathrm{Mg}_{3} \mathrm{Al}_{1-\mathrm{x}} \mathrm{Bi}_{\mathrm{x}}$ [4]. Therefore, the $\mathrm{Mg}_{3} \mathrm{Al}_{1-\mathrm{x}} \mathrm{Bi}_{\mathrm{x}}$ with lower substitutional level of $\mathrm{Bi}$ were synthesized and investigated in this study. The XRD patterns of bismuth-substituted $\mathrm{Mg}_{3} \mathrm{Al}_{1-\mathrm{x}} \mathrm{Bi}_{\mathrm{x}}$ LDH samples (where $\mathrm{x}$ was from $0 \%$ to $20 \%$ ) synthesized by co-precipitation method are shown in Fig. 2. As seen, with introduction of $\mathrm{Bi}^{3+}$ to the $\mathrm{LDH}$ structure, the side phase $\mathrm{Bi}_{2} \mathrm{O}_{2} \mathrm{CO}_{3}$ (PDF [41-1488]) along with $\mathrm{Mg}_{3} \mathrm{Al}_{1-\mathrm{x}} \mathrm{Bi}_{\mathrm{x}} \mathrm{LDHs}$ is forming. With increasing substitutional level of bismuth up to $\mathrm{x}=0.2$ the intensity of the reflections of $\mathrm{Mg}_{3} \mathrm{Al}_{1-\mathrm{x}} \mathrm{Bi}_{\mathrm{x}}$ phases decreased and $\mathrm{Bi}_{2} \mathrm{O}_{2} \mathrm{CO}_{3}$ phases increased, respectively. The XRD patterns of LDH samples obtained after the reconstruction process of sol-gel derived mixed-metal oxides are presented in Fig. 3. As seen, $\mathrm{Mg} / \mathrm{Al} / \mathrm{Bi}$ mixedmetal oxides synthetized by sol-gel method were successfully reconstructed to the layered structure since the single phase $\mathrm{Mg}_{3} \mathrm{Al}_{1} \mathrm{LDH}$ was obtained. Intense and narrow diffraction peaks at about $11^{\circ}$ and $22^{\circ}$, ascribed to $\left(\begin{array}{lll}0 & 0 & 3\end{array}\right)$ and $\left(\begin{array}{lll}0 & 0 & 6\end{array}\right)$ 
planes, respectively, are clearly seen in the XRD patterns of sol-gel derived $\mathrm{Mg}_{3} \mathrm{Al}_{1} \mathrm{LDH}$. In case of Bi-containing LDHs, negligible amount of $\mathrm{Bi}_{2} \mathrm{O}_{3}$ (PDF 41-1449) have formed during the sol-gel processing.

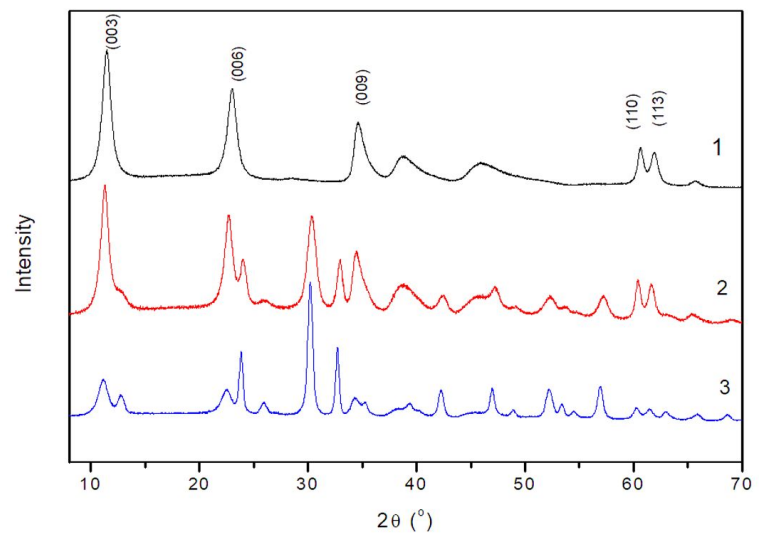

Fig. 2. XRD patterns of $\mathrm{Mg}_{3} \mathrm{Al}_{1-\mathrm{x}} \mathrm{Bi}_{\mathrm{X}}$ LDHs synthesized by co-precipitation method. The amount of $\mathrm{Bi}: \mathrm{x}=0$ (1), $\mathrm{x}=0.1$ (2) and $\mathrm{x}=0.2$ (3). The characteristic diffraction reflections of the LDH phase are indexed.

Lattice parameters a and c of the synthesized LDH samples were calculated from XRD patterns. The obtained cell parameters of $\mathrm{Mg} / \mathrm{Al} \mathrm{LDH}$ prepared using co-precipitation ( $\mathrm{a}=3.051 \AA$ and $\mathrm{c}=23.192 \AA)$ and sol-gel $(\mathrm{a}=3.059 \AA$ and $\mathrm{c}=23.388 \AA$ ) methods are almost the same and are in a good agreement with the literature data [11]. In case of $\mathrm{Mg} / \mathrm{Al} / \mathrm{Bi}$ samples fabricated by both synthesis methods both a and $\mathrm{c}$ parameters increased with increasing substitutional level of bismuth from $\mathrm{a}=3.065 \AA$ and $\mathrm{c}=23.555 \AA\left(\mathrm{Mg}_{3} \mathrm{Al}_{0.9} \mathrm{Bi}_{0.1}\right)$ to $\mathrm{a}=3.074 \AA$ and $\mathrm{c}=23.829 \AA\left(\mathrm{Mg}_{3} \mathrm{Al}_{0.8} \mathrm{Bi}_{0.2}\right)$ for co-precipitated samples and from $\mathrm{a}=3.066 \AA$ and $\mathrm{c}=23.521 \AA\left(\mathrm{Mg}_{3} \mathrm{Al}_{0.9} \mathrm{Bi}_{0.1}\right)$ to $\mathrm{a}=3.068 \AA$ and $\mathrm{c}=23.908 \AA\left(\mathrm{Mg}_{3} \mathrm{Al}_{0.8} \mathrm{Bi}_{0.2}\right)$ for sol-gel derived samples. This is not surprising since the ionic radius of $\mathrm{Bi}^{3+}(1.03 \AA)$ is much larger than that of $\mathrm{Al}^{3+}(0.535 \AA)$. The results of XRD analysis prove the existence of partial substitution of aluminum by bismuth in the LDH samples.

The SEM micrographs of the representative $\mathrm{Mg}_{3} \mathrm{Al}_{1-\mathrm{x}} \mathrm{Bi}_{\mathrm{x}} \mathrm{LDH}$ samples prepared by co-precipitation and sol-gel methods are

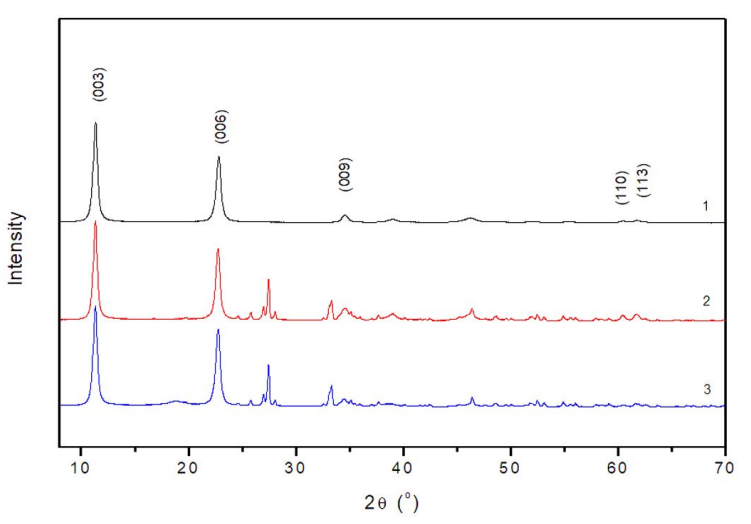

Fig. 3. XRD patterns of $\mathrm{Mg}_{3} \mathrm{Al}_{1-\mathrm{x}} \mathrm{Bi}_{\mathrm{x}}$ LDHs synthesized by sol-gel method. The amount of $\mathrm{Bi}$ : $\mathrm{x}=0$ (1), $\mathrm{x}=0.1$ (2) and $\mathrm{x}=0.2$ (3). The characteristic diffraction reflections of the LDH phase are indexed.

shown in Fig. 4. The characteristic microstructure of $\mathrm{Mg}_{3} \mathrm{Al}_{1-\mathrm{x}} \mathrm{Bi}_{\mathrm{x}}$ LDHs synthesized by co-precipitation method could be determined from the SEM micrographs. The formation of plate-like particles $0.5 \mu \mathrm{m}$ to $1.5 \mu \mathrm{m}$ in size is evident. The surface morphology of sol-gel derived $\mathrm{Mg}_{3} \mathrm{Al}_{1-\mathrm{x}} \mathrm{Bi}_{\mathrm{x}} \mathrm{LDH}$ samples also consists of the metal hydroxide sheets with the plate-like shaped particles varying in size from approximately $200 \mathrm{~nm}$ to $500 \mathrm{~nm}$. Thus, the nanocrystalline nature of the sol-gel derived $\mathrm{Mg}_{3} \mathrm{Al}_{1-\mathrm{x}} \mathrm{Bi}_{\mathrm{x}} \mathrm{LDH}$ powders with the narrow size distribution of crystallites was observed.

It was previously determined for pure $\mathrm{Mg}_{3} \mathrm{Al}_{1}$ LDH dry sample that at temperatures above $200 \mathrm{~K}$, Maxwell-Wagner relaxation could be observed [12]. At lower temperatures, very small losses were observed confirming the lack of conductivity in this material at studied frequencies. Temperature dependencies of real and imaginary parts of complex dielectric permittivity of $\mathrm{Mg}_{3} \mathrm{Al}_{1-\mathrm{x}} \mathrm{Bi}_{\mathrm{x}} \mathrm{LDH}$ samples prepared by coprecipitation method are shown in Fig. 5. The real part of complex permittivity $\epsilon^{\prime}$ is almost constant (5.5 to 6.5) for vacuumed and non-vacuumed samples. Only non-vacuumed $\mathrm{Mg}_{3} \mathrm{Al}_{0.9} \mathrm{Bi}_{0.1}$ sample shows frequency dispersion at higher temperature $(>200 \mathrm{~K})$. The dispersion can be explained on the basis of complex structure of synthesized 


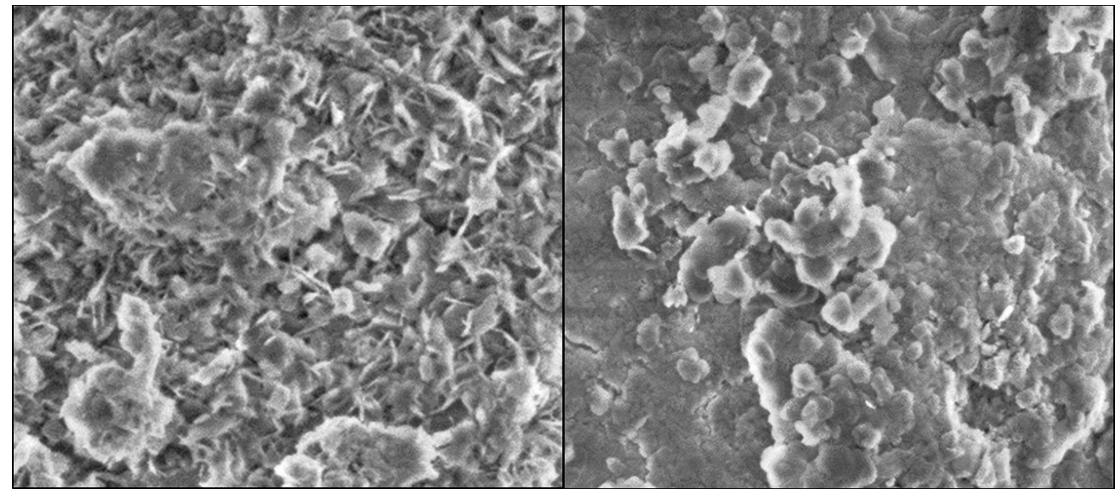

(a)

(b)

Fig. 4. SEM micrographs of $\mathrm{Mg}_{3} \mathrm{Al}_{0.9} \mathrm{Bi}_{0.1}$ synthesized by co-precipitation (a) and sol-gel (b) methods.
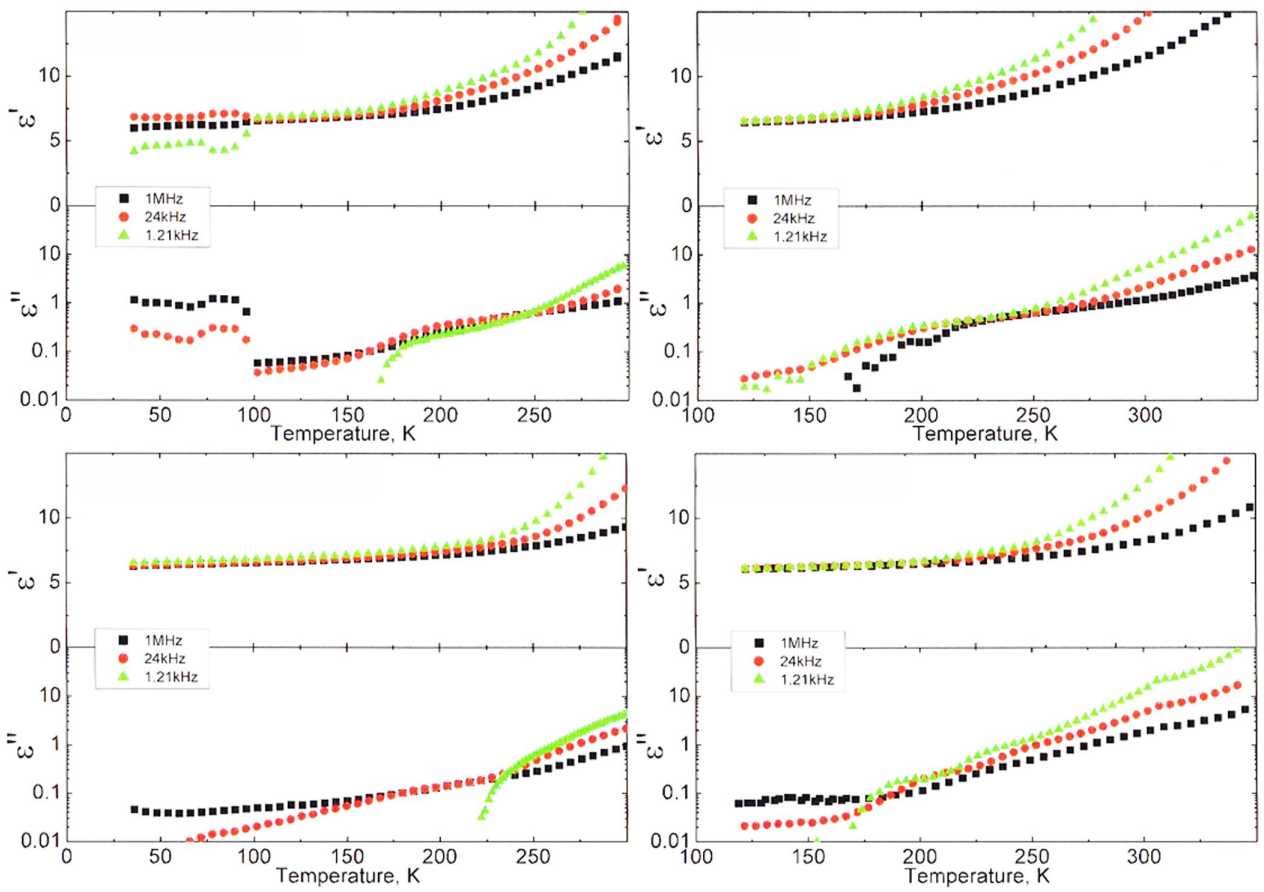

Fig. 5. Temperature dependencies of real $\epsilon^{\prime}$ and imaginary $\epsilon^{\prime \prime}$ parts of complex dielectric permittivity of $\mathrm{Mg}_{3} \mathrm{Al}_{0.9} \mathrm{Bi}_{0.1}$ (top) and $\mathrm{Mg}_{3} \mathrm{Al}_{0.8} \mathrm{Bi}_{0.2}$ (bottom) $\mathrm{LDH}$ samples prepared by co-precipitation method. The results for vacuumed samples are presented on the left.

LDH having bismuth as dopant that forms intrinsic electric moments [13]. Both parts of the complex dielectric permittivity decreased with increasing measurement frequency.

The temperature dependence of real and imaginary parts of complex dielectric permittivity of $\mathrm{Mg}_{3} \mathrm{Al}_{0.9} \mathrm{Bi}_{0.1}$ LDH sample prepared by sol-gel method is very similar (Fig. 6). The increase in $\epsilon^{\prime}$ is more pronounced at higher temperatures and at lower frequencies for non-vacuumed sample. This may be due to the frequency dependent orientational polarization [14]. Evidently, the dielectric properties of $\mathrm{Mg}_{3} \mathrm{Al}_{1-\mathrm{x}} \mathrm{Bi}_{\mathrm{x}} \mathrm{LDH}$ samples do not depend on surface morphology, consequently on the preparation technique [15]. 


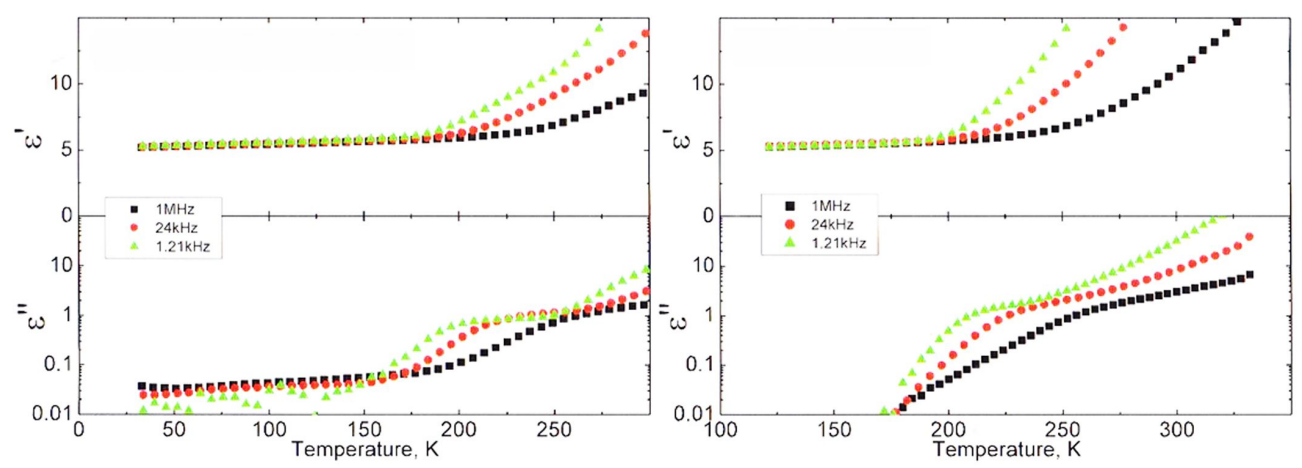

Fig. 6. Temperature dependencies of real $\epsilon^{\prime}$ and imaginary $\epsilon^{\prime \prime}$ parts of complex dielectric permittivity of $\mathrm{Mg}_{3} \mathrm{Al}_{0.9} \mathrm{Bi}_{0.1} \mathrm{LDH}$ prepared by sol-gel method. The results for vacuumed samples are presented on the left.
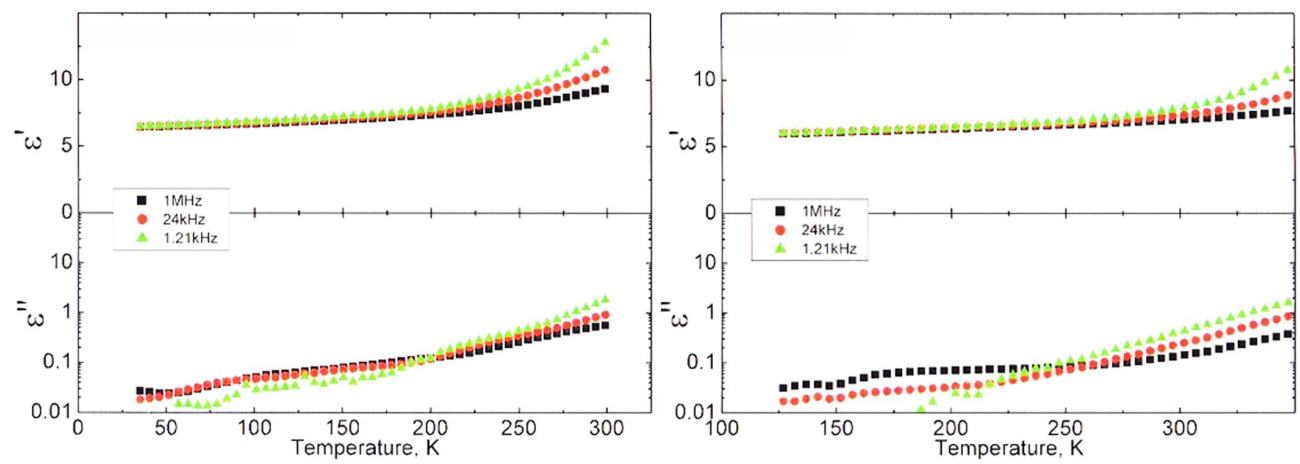

Fig. 7. Temperature dependencies of real $\epsilon^{\prime}$ and imaginary $\epsilon^{\prime \prime}$ parts of complex dielectric permittivity of $\mathrm{Mg}_{3} \mathrm{Al}_{0.8} \mathrm{Bi}_{0.2} \mathrm{LDH}$ prepared by sol-gel method. The results for vacuumed samples are presented on the left.

Fig. 7 reveals the temperature dependence of dielectric permittivity of $\mathrm{Mg}_{3} \mathrm{Al}_{0.8} \mathrm{Bi}_{0.2} \mathrm{LDH}$ synthesized by sol-gel route.

With increasing temperature, permittivity plateau is observed for the studied frequencies and shifts only slightly with further increasing of temperature. Evidently, structural transition is not observed for all bismuth-doped $\mathrm{LDH}$ samples [16, 17]. Moreover, the increase of $\epsilon^{\prime}$ with increasing temperature indicates the semiconducting behavior of our $\mathrm{Mg}_{3} \mathrm{Al}_{1-\mathrm{x}} \mathrm{Bi}_{\mathrm{x}} \mathrm{LDH}$ samples [18].

\section{Conclusions}

Bismuth containing magnesium-aluminum layered double hydroxides $\mathrm{LDH} \mathrm{Mg}_{3} \mathrm{Al}_{1-\mathrm{x}} \mathrm{Bi}_{\mathrm{x}}$ $(x \leqslant 0.2)$ were synthesized by co-precipitation and sol-gel methods. According to the XRD results, the single phase $\mathrm{Mg}_{3} \mathrm{Al}_{1-\mathrm{x}} \mathrm{Bi}_{\mathrm{x}}$ has formed in the sol-gel processing. However, the side $\mathrm{Bi}_{2} \mathrm{O}_{2} \mathrm{CO}_{3}$ phase has formed during the synthesis by co-precipitation method. The both a and $\mathrm{c}$ lattice parameters of $\mathrm{Mg}_{3} \mathrm{Al}_{1-\mathrm{x}} \mathrm{Bi}_{\mathrm{x}}$ increased with increasing substitutional level of bismuth indicating the existence of partial substitution of aluminum by bismuth in the LDH samples. The temperature dependence of dielectric permittivity of $\mathrm{Mg}_{3} \mathrm{Al}_{1-\mathrm{x}} \mathrm{Bi}_{\mathrm{x}} \mathrm{LDH}$ samples prepared by different methods was also investigated in this study. In general, the increase in $\epsilon^{\prime}$ was more pronounced at higher temperatures and at lower frequencies for non-vacuumed samples. The dielectric properties were independent 
of surface morphology of $\mathrm{Mg}_{3} \mathrm{Al}_{1-\mathrm{x}} \mathrm{Bi}_{\mathrm{x}} \mathrm{LDH}$ samples fabricated by two different synthesis routes. Finally, no structural transitions were observed for all bismuth-doped LDH samples. The real part of complex permittivity $\epsilon^{\prime}$ was almost constant $(5.5$ to 6.5) for $\mathrm{Mg}_{3} \mathrm{Al}_{1-\mathrm{x}} \mathrm{Bi}_{\mathrm{x}} \mathrm{LDH}$ samples prepared by co-precipitation method, however, it was slightly dependent on the amount of $\mathrm{Bi}$ in case of sol-gel derived $\mathrm{Mg}_{3} \mathrm{Al}_{1-\mathrm{x}} \mathrm{Bi}_{\mathrm{x}} \mathrm{LDH}$ samples.

\section{Acknowledgements}

The work has been done in frame of the project TUMOCS: Tuneable Multiferroics Based on Oxygen Octahedral Structures. This project has received funding from the European Union's Horizon 2020 research and innovation program under the Marie Skłodowska-Curie Grant Agreement No. 645660.

\section{References}

[1] Khan A.I., O’Hare D., J. Mater. Chem., 12 (2002), 3191.

[2] WANG Y., GaO H., J. Coll. Interf. Sci., 301 (2006), 19.

[3] Jaiswal A., Chattopadhyaya M.C., Arab. J. Chem., 10 (2017), S2457.

[4] Sokol D., Salak A.N., Ferreira M.G.S., BeganSKIENE A., KAREIVA A., J. Sol-Gel Sci. Technol., 85 (2018), 221.

[5] Salak A.N., Ferreira V.M., J. Eur. Ceram. Soc., 27 (2007), 2887.

[6] Salak A.N., Ferreira V.M., Ribeiro J.L., Vieira L.G., Pullar R.C., Alford N.MCN., J. Appl. Phys., 104 (2008), 014105.

[7] Khalyavin D.D., Salak A.N., Olekhnovich N.M., PushKarev A.V., RAdyUsh YU.V., Manuel P., RAeVsKi I.P., ZheludKeVICH M.L., FERreira M.G.S., Phys. Rev. B, 89 (2014), 174414.
[8] Khalyavin D.D., SalaK A.N., LOPES A.B., OLEKHNOVICH N.M., PUSHKAREV A.V., Radyush Yu.V., Fertman E.L., Desnenko V.A., Fedorchenko A.V., Manuel P., Feher A., Vieira J.M., Ferreira M.G.S., Phys. Rev. B, 92 (2015), 224428.

[9] Zarkov A., Mikoliunaite L., Katelnikovas A., Tautkus S., Kareiva A., Chem. Papers, 72 (2018), 129.

[10] Smalenskaite A., Vieira D.E.L., Salak A.N., Ferreira M.G.S., Katelnikovas A., Kareiva A., Appl. Clay Sci., 143 (2017), 175.

[11] Evans D.E., Slade R.C.T., In Structure \& Bonding, Springer-Verlag: Berlin, Germany, 119 (2005), 1.

[12] IVAnov M., Klemkaite K., Khinsky A., Kareiva A., BAnYs J., Ferroelectr, 417 (2011), 136.

[13] Kaur P., Bahel S., Narang S.B., Mater. Res. Bull., 100 (2018), 275.

[14] Duhan S., Sanghi S., Agarwal A., Sheoran A., Rani S., Physica B, 404 (2009), 1648.

[15] Pozingis J., MaCUTKeviC J., Grigalaitis R., Banys J., Lupascu D.C., Ceram. Int., 40 (2014), 9961.

[16] Vijatovic Petrovic M.M., Grigalaitis R., Ilic N., Bobic J.D., Dzunuzovic A., Banys J., Stojanovic B.D., J. Alloy. Compd., 724 (2017), 959.

[17] LuO S., WANG K., Scripta Mater., 114 (2018), 160.

[18] Siddique M.N., Ahmed A., Tripathi P., J. Allou. Compd., 735 (2018), 516.
Received 2018-03-07 Accepted 2019-04-19 